\title{
Pengaruh Konsentrasi Belajar dan Lingkungan Belajar terhadap Hasil Belajar Matematika pada Pembelajaran Daring
}

\author{
Yuliana ${ }^{1, *}$, Hanifah Alifiananta Anindita ${ }^{2}$, Muhammad Wahid Syaifuddin ${ }^{3}$ \\ ${ }^{1,2,3}$ Universitas Widya Dharma Klaten \\ *pakyulikids@unwidha.ac.id
}

\begin{tabular}{|l|l|l|l|}
\hline Received : 31-08-2021 & Revised: 25-10-2021 & Accepted: 27-10-2021 & Published: $21-12-2021$ \\
\hline
\end{tabular}

\begin{abstract}
ABSTRAK
Melalui penelitian ini, peneliti menganalisis pengaruh konsentrasi belajar siswa maupun kondisi lingkungan belajar siswa atas hasil belajar matematika pada pembelajaran daring, baik secara terpisah maupun secara bersama-sama. Dalam mendukung tercapainya tujuan penelitian ini, sampel dipilih secara cluster random sampling. Dari sampel tersebut terkumpullah data menggunakan angket secara online serta tes menggunakan Quizizz. Melalui angket terhimpun data konsentrasi belajar siswa serta data lingkungan belajar siswa, sedangkan melalui tes terhimpun data hasil belajar matematika. Setelah data terkumpul, data tersebut dianalisis menggunakan regresi linear berganda. Dari penelitian ini diperoleh simpulan bahwa konsentrasi belajar siswa serta kondisi lingkungan belajar siswa memberikan dampak positif yang signifikan secara terpisah maupun bersamaan atas hasil belajar matematika dalam pembelajaran daring.
\end{abstract}

Kata Kunci : konsentrasi belajar, lingkungan belajar, hasil belajar matematika, pembelajaran daring.

\section{ABSTRACT}

Through this study, researchers analyzed the effect of student learning concentration and student learning environment, on mathematics learning outcomes in online learning, both separately and together. To support the achievement of the objectives of this study, the sample was selected by cluster random sampling. From the sample, data were collected using online questionnaires and tests using Quizizz. Through a questionnaire, data on student learning concentration and data on student learning environments are collected, while through tests, data on mathematics learning outcomes is collected.After the data is collected, the data is analyzed using multiple linear regression. From this study, it was concluded that the concentration of student learning and the student's learning environment had a significant positive influence separately and simultaneously on the learning outcomes of mathematics in online learning.

Keywords: learning concentration, learning environment, math learning outcomes, online learning.

\section{PENDAHULUAN}

Indonesia termasuk sebagai negara di dunia yang berpotensi besar rawan terhadap bencana alam karena berada dalam wilayah ring of fire (Gosal, Tarore, \& Karongkong, 2018). Sebagaimana negara-negara lain di dunia yang masuk dalam wilayah seperti ini, bencana alam seperti gempa bumi, tsunami, banjir, ataupun tanah longsor selalu mengintai setiap saat. Apalagi daerah-daerah di Yogyakarta dan Jawa Tengah, selama dekade teakhir 
ini sudah mengalami banyak sekali bencana alam diantaranya gempa bumi, tanah longsor, banjir, dan gunung meletus (Widayatun \& Fatoni, 2013). Tidak jarang wilayah yang terkena bencana alam harus menghentikan kegiatan persekolahannya dalam waktu yang lumayan cukup lama, sebagaimana seperti pada saat pandemi covid 19 yang masih tengah berlangsung hingga sekarang ini.

Sudah lebih dari dua tahun, pandemi covid 19 masih melanda di Indonesia. Bahkan, pada pertengahan tahun 2021 ini terjadi lonjakan kasus tertinggi (Septian, Ramadhanty, Darhim, \& Prabawanto, 2021). Keadaan ini tentu semakin menganggu pelaksanaan kegiatan pembelajaran. Pada situasi pandemi covid 19 seperti sekarang ini, kegiatan pembelajaran via daring masih menjadi alternatif terbaik agar pembelajaran bagi siswa masih tetap dapat berjalan. Seperti yang terjadi di Sekolah Sekolah Menengah Atas Negeri 1 Cawas. Sekolah Menengah Atas Negeri 1 Cawas berlokasi di Kabupaten Klaten, Provinsi Jawa Tengah. Sejak Maret 2019 hingga pertengahan tahun 2021, sekolah tersebut berlangsung kegiatan pembelajaran daring. Siswa-siswi harus beradaptasi dengan beberapa fitur pembelajaran daring. Bahkan, para guru semakin berinovasi dalam mengembangkan pembelajaran daring agar pembelajaran semakin menarik. Fasilitas sarana dan prasarana yang mendukung di sekolah ini, sehingga pembelajaran daring menggunakan platform google classroom, LMS, Youtube, Zoom ataupun WAG semakin lebih familiar (Suryawan \& Permana, 2020).

Selama pembelajaran daring, sebagian besar siswa belajar di rumah. Ada kalanya, siswa belajar didampingi oleh orang tua ataupun bersama saudara-saudaranya. Akan tetapi, sebagian siswa belajar di rumah tanpa didampingi oleh kedua orang tua. Dengan melihat keadaan ini, pendampingan orang tua dalam pembelajaran daring sangat dibutuhkan oleh siswa (Hakim, 2020; Kusumaningrum, Singgih Kuncoro, \& Astuti Arigiyati, 2020; Ratiwi $\&$ Sumarni, 2020). Ironisnya, tidak semua orang tua mampu dalam mendampingi anakanaknya ketika ada pembelajaran daring (Anugrahana, 2020). Sebagian orang tua beralasan bekerja di luar rumah, sebagian lagi orang tua tidak mampu karena materi pembelajarannya ataupun penggunaan sarana. Apalagi pembelajaran matematika di Sekolah Menengah Atas, siswa sudah dianggap mandiri sehingga orang tua beranggapan tidak perlu mendampinginya. Sebagian orang tua tidak mampu untuk mendampingi pembelajaran daring dikarenakan materi matematika yang sudah terlalu sulit atau sudah tingkat tinggi. Oleh karena itu, sebagian pembelajaran daring di Sekolah Menengah Atas tidak didampingi oleh orang tua. Lantas, apakah yang perlu dilakukan oleh orang tua agar 
hasil pembelajaran daring di Sekolah Menengah Atas dapat tetap berjalan efektif dengan didampingi orang tua maupun tanpa didampingi oleh orang tua mereka?

Pendampingan orang tua dalam pembelajaran daring memiliki peranan penting terhadap hasil belajar yang dicapai oleh putra-putrinya. Akan tetapi, terdapat faktor-faktor lain ternyata juga berefek atas peningkatan hasil belajar siswa (Dakhi, 2020). Hasil belajar siswa tergantung oleh dua komponen yang meliputi aspek yang berasal dari dalam diri siswa maupun aspek yang berasal dari luar diri siswa (Slameto, 2015). Aspek berpengaruh dari luar siswa, diantaranya lingkungan keluarga, sekolah, dan masyarakat. Sedangkan aspek yang berasal dari dalam siswa, meliputi kesehatan tubuh, minat belajar, intelegensi, motivasi belajar, serta konsentrasi belajar (Rizkiani \& Septian, 2019).

Desain pembelajaran daring berkaitan dengan aspek lingkungan belajar siswa dan konsentrasi belajar siswa. Lingkungan belajar terdiri atas lingkungan fisik maupun lingkungan sosial memiliki pengaruh terhadap proses belajar serta hasil belajar (Halim \& Rahma, 2020; Wahyuningsih \& Djazari, 2013). Lingkungan belajar kondusif perlu diciptakan oleh siswa maupun orang tua agar berdampak baik pada motivasi belajar (Pahriji, 2021) dan hasil belajar yang diperolehnya. Pembelajaran daring membuat siswa dituntut dapat beradaptasi dengan lingkungan belajar baru. Kondisi rumah masing-masing siswa tentu sangat berbeda dengan kondisi ruang kelas di sekolah. Ruang kelas di sekolah merupakan ruang khusus untuk belajar yang biasanya dilengkapi dengan fasilitas belajar yang mendukung pembelajaran. Berbeda dengan kondisi di rumah, rumah sebagai tempat belajar cenderung memiliki keterbatasan fasilitas belajar. Selain siswa di rumah tidak adanya pendampingan belajar oleh orang tua, beberapa kendala yang masih dapat ditemui pembelajaran di rumah, seperti tidak adanya ruang khusus belajar, kondisi rumah yang gaduh, aktivitas masyarakat yang bising, dan sarana pembelajaran yang kurang memadai membuat hambatan tersendiri bagi kegiatan belajar yang dilakukan oleh siswa.

Tak hanya lingkungan belajar, konsentrasi belajar perlu diciptakan oleh anak saat pembelajaran daring. Hal ini tentu sangat didukung oleh guru maupun orang tua siswa. Konsentrasi belajar merupakan kegiatan dalam memusatkan pikiran maupun perhatian pada suatu objek (Ahmadi, 2017). Dalam kegiatan pembelajaran daring, konsentrasi yang memadai sangat diperlukan oleh siswa karena siswa bertemu gurunya melalui tatap maya. Apabila siswa tidak berkonsentrasi dalam pembelajaran, lantas tertinggal pembelajaran beberapa menit saja maka akan berefek pada pembelajaran selanjutnya. Konsentrasi yang baik akan membuat siswa lebih fokus dalam belajar. Ketika siswa berkonsentrasi dengan baik ketika pembelajaran daring, fokus belajarnya tidak akan terpecah-pecah sehingga 
pikirannya lebih terpusat pada pembelajaran yang disampaikan oleh gurunya. Itulah harapannya, pembelajaran daring harus didesain agar pembelajarannya kondusif dan mampu menciptakan konsentrasi belajar anak. Bagaimanakah pengaruh konsentrasi dan lingkungan belajar siswa terhadap hasil pembelajaran daring? Untuk mengetahuinya, masih perlu diteliti lebih lanjut.

Meninjau dari penelitian terdahulu, banyak penelitian dilakukan untuk menganalisis faktor-faktor yang berpengaruh terhadap pembelajaran daring. Salah satunya, penelitian menganalisis pendukung dan penghambat dalam pembelajaran daring yang menyebutkan bahwa fasilitas dan kegiatan orang tua menjadi penentu keberhasilan proses pembelajaran daring melalui pendekatan kualitatif (Putria, Maula, \& Uswatun, 2020). Dalam penelitian studi literatur lainnya menyebutkan bahwa terdapat tiga dimensi yang menjadi penentu keberhasilan pembelajaran daring, yang meliputi dimensi personal, dimensi lingkungan, dan dimensi sistem (Pangondian, Santosa, \& Nugroho, 2019). Sementara itu, penelitian deskripsi korelasi juga telah menunjukkan bahwa siswa yang berkonsentrasi belajar cukup baik pada masa pendemi ternyata berkorelasi positif terhadap prestasi belajar siswa (Riinawati, 2021).

Berdasarkan uraian yang disebutkan di atas, dua aspek yang dapat dipertimbangkan oleh orang tua agar pembelajaran daring bagi anak-anaknya dapat berjalan dengan baik, yaitu lingkungan belajar dan konsentrasi belajar siswa. Didasari oleh penelitian sebelumnya tersebut, peneliti sangat tertarik untuk menganalisis pengaruh konsentrasi belajar siswa maupun lingkungan belajar siswa atas hasil belajar siswa dalam pembelajaran daring.

\section{METODE PENELITIAN}

Penelitian ini merupakan kuantitatif. Ditinjau dari masalah yang dikaji, penelitian ini merupakan penelitian korelasional karena variabelnya memiliki hubungan sebab akibat. Desain hasil belajar (Y) sebagai variabel terikat, sedangkan konsentrasi belajar siswa $\left(\mathrm{X}_{1}\right)$ dan lingkungan belajar siswa $\left(\mathrm{X}_{2}\right)$ sebagai variabel bebasnya.

Dari siswa-siswi Sekolah Menengah Atas Negeri 1 Cawas dipilihlah sampel penelitian. Melalui metode cluster random sampling terkumpullah dua kelas penelitian. Melalui angket dikumpulkannya data kuantitatif konsentrasi belajar siswa dan data kuantitatif kondisi lingkungan belajar siswa. Sementara itu, melalui tes belajar siswa terkumpul data hasil belajar matematika siswa. Sejalan dengan kondisi pembelajaran daring, angket dibagikan kepada siswa secara daring dengan berbantuan Google Form dan tes belajar disajikan dalam Quizizz yang dibagikan secara online. Pada angket konsentrasi 
dan lingkungan belajar siswa, masing-masing angket tersusun atas 30 butir pernyataan. Sedangkan, pada tes belajar tersusun atas 20 butir pertanyaan berbentuk pilihan ganda. Penilaian angket menggunakan bobot 1 hingga 4, sedangkan pada tes hasil belajar menggunakan bobot 1 bagi setiap jawaban yang benar dan bobot 0 bagi setiap jawaban salah. Agar mempermudah penyebarannya, angket dibagikan kepada siswa dengan link : http://bit.ly/Angket_KonsentrasiBelajar dan http://bit.ly/Angket_LingkunganBelajar, serta tes belajar dibagikan kepada siswa dengan link : https://quizizz.com/join?gc=48815554.

Angket maupun soal belajar matematika dilakukan kebenaran isinya oleh para ahli, dilakukan uji validitas serta uji reliabilitas. Sementara itu, soal tes hasil belajar matematika dilakukan uji validitas, uji reliabilitas, uji tingkat kesukaran, maupun uji daya pembeda (Ghozali, 2016; Suharsimi, 2013). Melalui uji coba yang telah dilaksanakan, pernyataan dalam angket konsentrasi belajar yang memenuhi syarat validitas maupun reliabilitas sebanyak 28 butir dan pernyataan angket lingkungan belajar yang memenuhi sebanyak 26. Sementara itu, pertanyaan pada soal tes belajar terdapat 17 butir pertanyaan yang memenuhi syarat validitas, reliabilitas, taraf kesukaran, serta daya pembeda.

Butir angket dan butir soal yang memenuhi syarat digunak an sebagai alat ukur penelitian. Dari alat ukur tersebut terkumpul data kuantitatif konsentrasi belajar, data kuantitatif kondisi lingkungan belajar siswa, dan data kuantitatif hasil belajar matematika. Data yang telah terhimpun dianalisis dengan regresi linear. Untuk itu, prasyarat analisis regresi linear harus terpenuhi. Prasyarat dalam analisis regresi linear meliputi normalitas, linearitas, multikolinearitas, dan heteroskedastisitas (Febrianto, Dwidayati, \& Hendikawati, 2018; Pujilestari, Dwidayati, \& Sugiman, 2017).

Setelah keseluruhan prasyarat analisis terpenuhi, data dilakukan analisis pengujian hipotesis kesatu, hipotesis kedua, serta hipotesis ketiga menggunakan analisis regresi linear. Pada hipotesis kesatu maupun kedua, peneliti menduga bahwa konsentrasi belajar siswa maupun lingkungan belajar siswa secara terpisah mempunyai pengaruh positif atas hasil belajar matematika. Pada hipotesis ketiga, peneliti menduga bahwa konsentrasi belajar siswa dan lingkungan belajar siswa secara bersamaan mempunyai pengaruh positif terhadap hasil belajar matematika. Pada pengujian hipotesis pertama maupun kedua dilakukan dengan analisis regresi linear sederhana, sedangkan pada pengujian hipotesis ketiga dilakukan dengan analisis regresi linear berganda. Pengukuran besarnya pengaruh konsentrasi belajar dan lingkungan belajar terhadap hasil belajar matematika dianalisis menggunakan sumbangan efektif serta sumbangan relatif. 


\section{HASIL DAN PEMBAHASAN}

Dari angket dan tes yang telah memenuhi persyaratan di atas terkumpul data kuantitatif yang meliputi data konsentrasi belajar siswa, data lingkungan belajar siswa, serta data hasil belajar matematika siswa. Deskripsi ketiga data kuantitatif tersebut masingmasing tersaji pada Tabel 1., Tabel 2., dan Tabel 3. berikut ini.

Tabel 1. Deskripsi Data Konsentrasi Belajar

\begin{tabular}{cccc}
\hline $\begin{array}{c}\text { Data Konsentrasi } \\
\text { Belajar }\end{array}$ & Frekuensi & $\begin{array}{c}\text { Persentase } \\
(\%)\end{array}$ & Kategori \\
\hline $48-55$ & 12 & 11,1 & Rendah \\
$56-63$ & 12 & 11,1 & \\
\hline $64-71$ & 24 & 22,2 & Sedang \\
$72-79$ & 14 & 19,4 & \\
\hline $80-87$ & 33 & 30,6 & Tinggi \\
$88-95$ & 6 & 5,6 & \\
\hline Jumlah & 108 & 100 & \\
\hline
\end{tabular}

Data yang terangkum pada Tabel 1 menggambarkan keadaan tingkat konsentrasi belajar siswa. Konsentrasi belajar siswa dalam mengikuti pembelajaran daring sebanyak $22,2 \%$ siswa masih tergolong rendah, sedangkan sebanyak 41,6\% siswa tergolong sedang, dan sebanyak $36,2 \%$ siswa tergolong tinggi.

Tabel 2. Deskripsi Data Lingkungan Belajar

\begin{tabular}{cccc}
\hline $\begin{array}{c}\text { Data } \\
\text { Lingkungan } \\
\text { Belajar }\end{array}$ & Frekuensi & $\begin{array}{c}\text { Persentase } \\
(\%)\end{array}$ & Kategori \\
\hline $63-67$ & 9 & 8,3 & Rendah \\
$68-72$ & 6 & 5,6 & \\
\hline $73-77$ & 15 & 13,9 & Sedang \\
$78-82$ & 39 & 36,1 & \\
\hline $83-87$ & 24 & 22,2 & Tinggi \\
$88-92$ & 15 & 13,9 & \\
\hline Jumlah & 108 & 100 & \\
\hline
\end{tabular}

Data yang terangkum pada Tabel 2 menggambarkan kondisi lingkungan belajar siswa. Sebanyak 13,9\% siswa berada dalam lingkungan belajar yang masih tergolong rendah atau kurang kondusif untuk mengikuti pembelajaran daring, sedangkan sebanyak $50 \%$ siswa tergolong sedang atau kondusif namun belum sepenuhnya mendukung untuk mengikuti pembelajaran daring, dan sebanyak 36,1\% siswa tergolong tinggi atau sangat kondusif dan mendukung untuk untuk mengikuti pembelajaran daring.

Tabel 3. Deskripsi Data Hasil Belajar Matematika

\begin{tabular}{cccc}
\hline $\begin{array}{c}\text { Data Hasil } \\
\text { Belajar }\end{array}$ & Frekuensi & $\begin{array}{c}\text { Persentase } \\
(\%)\end{array}$ & Kategori \\
\hline $3-4$ & 9 & 8,3 & Rendah \\
$5-6$ & 24 & 22,2 & \\
\hline $7-8$ & 21 & 19,4 & Sedang
\end{tabular}




\begin{tabular}{cccc}
$9-10$ & 30 & 27,8 & \\
$11-12$ & 12 & 11,1 & \\
\hline $13-14$ & 6 & 5,6 & Tinggi \\
$15-16$ & 6 & 5,6 & \\
\hline Jumlah & 108 & 100 & \\
\hline
\end{tabular}

Data yang terangkum pada Tabel 3 mendeskripsikan pengelompokkan siswa menurut hasil belajarnya. Hasil belajar siswa masih tergolong rendah sebanyak 30,5\% siswa, sedangkan sebanyak 58,3\% siswa tergolong sedang, dan sebanyak 11,2\% siswa tergolong tinggi.

Dari deskripsi tersebut terlihat gambaran data yang terkumpul. Data yang dikumpulkan melalui angket berupa data ordinal. Untuk itu, data perlu ditransformasikan menjadi data berskala interval agar dapat dianalisis menggunakan statistika. Data ordinal dikonversikan menjadi data interval menggunakan metode suksesif interval (Hays, 1976). Setelah keseluruhan data terkonversi menjadi data interval, analisis berikutnya dilakukan uji prasyarat. Prasyarat yang harus terpenuhi dalam analisis regresi linear ganda meliputi normalitas, linearitas, multikolinearitas, dan heteroskedastisitas. Hasil analisis prasyarat normalitas mengunakan uji Kolmogorov-Smirnov terangkum pada Tabel 4.

Tabel 4. Normalitas dengan Uji Kolmogorov-Smirnov

\begin{tabular}{lcc}
\multicolumn{1}{c}{ Data } & Signifikansi & Kesimpulan \\
\hline Konsentrasi Belajar & 0,863 & Normal \\
Lingkungan Belajar & 0,940 & Normal \\
Hasil Belajar Matematika & 0,473 & Normal \\
\hline
\end{tabular}

Menurut hasil analisis di atas, nilai signifikansi masing-masing data lebih besar dari $5 \%$. Kondisi ini mendeskripsikan bahwa data konsentrasi belajar siswa, lingkungan belajar siswa, maupun hasil belajar matematika siswa yang telah terkumpul mengikuti distribusi normal dari populasinya. Jadi, normalitas sebagai persyaratan analisis sudah terpenuhi.

Prasyarat selanjutnya dengan menganalisis linearitas antara $\mathrm{X}_{1}$ dan $\mathrm{X}_{2}$ terhadap $\mathrm{Y}$. Analisis linearitas diuji dengan uji F, yang hasilnya tersaji pada Tabel 5.

Tabel 5. Linearitas dengan Uji $F$

\begin{tabular}{lcccl}
\hline Hubungan & $\mathrm{F}_{\text {hitung }}$ & Signifikansi & $\mathrm{F}_{\text {tabel }}$ & Kesimpulan \\
\hline Konsentrasi Belajar atas & 1,937 & 1,937 & 2,74 & Linear \\
$\begin{array}{l}\text { Hasil Belajar Matematika } \\
\text { Lingkungan Belajar atas }\end{array}$ & 0,957 & 0,957 & 2,34 & Linear \\
Hasil Belajar Matematika & & & \\
\hline
\end{tabular}

Menurut hasil uji F, $\mathrm{F}_{\text {hitung }}$ untuk konsentrasi belajar atas hasil belajar matematika lebih kecil dari $\mathrm{F}_{\text {tabel }}$ demikian juga $\mathrm{F}_{\text {hitung }}$ untuk lingkungan belajar atas hasil belajar matematika lebih kecil dari $\mathrm{F}_{\text {tabel. }}$ Begitu juga, nilai signifikansi untuk keduanya juga lebih 
dari 5\%. Dari perbandingan $F_{\text {hitung }}$ dengan $F_{\text {tabel }}$ dan nilai sigbifikansinya, maka memberikan arti bahwa adanya hubungan linear antara konsentrasi belajar atas hasil belajar matematika, demikian pula terdapat hubungan linear antara lingkungan belajar atas hasil belajar matematika. Dengan demikian, prasyarat linearitas telah terpenuhi.

Prasyarat berikutnya yaitu dengan menganalisis multikolinearitas antara konsentrasi belajar dengan lingkungan belajar siswa. Hasil analisis multikolinearitas terangkum pada Tabel 6 .

Tabel 6. Analisis Multikolinearitas

\begin{tabular}{clc}
\hline & & Lingkungan Belajar \\
\hline Konsentrasi & Korelasi Pearson & 0,672 \\
Belajar & Signifikansi & 0,000
\end{tabular}

Menurut hasil analisis pada Tabel 6 diperoleh nilai interkorelasi antara konsentrasi belajar dengan kondisi lingkungan belajar sebesar 0,672 lebih kecil dari 0,8. Kondisi ini menjelaskan bahwa tidak terjadinya multikolinearitas antara konsentrasi belajar dengan lingkungan belajar sehingga model regresi linear berganda yang nantinya terbentuk akan terbebas dari masalah multikolinearitas.

Prasyarat selanjutnya dengan melakukan analisis heteroskedastisitas. Model regresi linear berganda yang baik harus terbebas dari masalah heteroskedasitas. Hasil analisis heteroskedastisitas terangkum pada Tabel 7.

Tabel 7. Analisis Heteroskedastisitas

\begin{tabular}{ccc}
\hline Data & Signifikansi & Kesimpulan \\
\hline Konsentrasi Belajar & 0,743 & Homoskedastisitas \\
\hline Lingkungan Belajar & 0,804 & Homoskedastisitas \\
\hline
\end{tabular}

Menurut hasil analisis pada Tabel 7 menunjukkan nilai signifikansi sebesar 0,743. Sementara itu, nilai signifikansi lingkungan belajar sebesar 0,804. Keduanya, nilai signifikansi konsentrasi belajar maupun lingkungan belajar tidak kurang dari 5\% sehingga tidak terjadi heteroskedatisitas dalam model regresi linear berganda. Dengan demikian, asumsi homoskedastisitas telah terpenuhi.

Semua analisis prasyarat regresi linear telah terpenuhi. Lantas, analisis yang perlu dilakukan meliputi pengujian hipotesis kesatu, hipotesis kedua, serta hipotesis ketiga.

Pada hipotesis kesatu didapatkan model regresi $\mathrm{Y}=-4,887+0,163 \mathrm{X}_{1}$. Hal ini terlihat dari pada Tabel 8 . 
Tabel 8. Hipotesis Pertama

\begin{tabular}{|c|c|c|c|c|c|}
\hline \multirow[t]{2}{*}{ Model } & \multicolumn{2}{|c|}{$\begin{array}{c}\text { Koefisien } \\
\text { Tidak Terstandar }\end{array}$} & \multirow{2}{*}{$\begin{array}{c}\begin{array}{c}\text { Koefisien } \\
\text { Terstandar }\end{array} \\
\text { Beta }\end{array}$} & \multirow[b]{2}{*}{ t hitung } & \multirow[b]{2}{*}{ Signifikansi } \\
\hline & B & $\begin{array}{l}\text { Kesalahan } \\
\text { Baku }\end{array}$ & & & \\
\hline Konstan & $-4,887$ & 2,300 & & $-2,125$ & 0,041 \\
\hline Konsentrasi Belajar & 0,163 & 0,028 & 0,707 & 5,831 & 0,000 \\
\hline
\end{tabular}

Dalam menguji model regresi sederhana terhadap sebuah variabel bebas maka dilakukan uji hipotesis secara parsial dengan uji t. Menurut Tabel 8 didapatkan nilai signifikansi $=0,0$ yang nilainya tidak lebih besar dari $5 \%$. Hasil analisis ini memberikan kesimpulan yang signifikan bahwa konsentrasi belajar memberikan efek positif atas hasil belajar matematika pada pembelajaran daring.

Pada hipotesis kedua didapatkan model regresi $\mathrm{Y}=-12,390+0,235 \mathrm{X}_{2}$. Hal ini terlihat dari pada Tabel 9.

Tabel 9. Hipotesis Kedua

\begin{tabular}{|c|c|c|c|c|c|}
\hline \multirow[t]{2}{*}{ Model } & \multicolumn{2}{|c|}{$\begin{array}{c}\text { Koefisien } \\
\text { Tidak Terstandar }\end{array}$} & \multirow{2}{*}{$\begin{array}{c}\begin{array}{c}\text { Koefisien } \\
\text { Terstandar }\end{array} \\
\text { Beta }\end{array}$} & \multirow[b]{2}{*}{ t hitung } & \multirow[b]{2}{*}{ Signifikans } \\
\hline & $\mathrm{B}$ & $\begin{array}{l}\text { Kesalahan } \\
\text { Baku }\end{array}$ & & & \\
\hline Konstan & $-12,390$ & 3,701 & & $-3,348$ & 0,002 \\
\hline Lingkungan Belajar & 0,235 & 0,042 & 0,695 & 5,632 & 0,000 \\
\hline
\end{tabular}

Dalam menguji model regresi sederhana terhadap sebuah variabel bebas maka dilakukan uji hipotesis secara parsial dengan uji t. Menurut Tabel 10 didapatkan nilai signifikansi $=0,0$ yang nilainya tidak lebih besar dari 5\%. Hasil analisis ini memberikan simpulan yang signifikan bahwa lingkungan belajar siswa memberikan pengaruh positif terhadap hasil belajar matematika pada pembelajaran daring.

Pada hipotesis ketiga didapatkan model regresi $\mathrm{Y}=-11,802+0,101 \mathrm{X}_{1}+0,136 \mathrm{X}_{2}$. Hal ini terlihat dari pada Tabel 10 dan Tabel 11 berikut.

Tabel 10. Uji Keberartian Koefisien Regresi

\begin{tabular}{lccccc}
\hline \multirow{2}{*}{ Model } & \multicolumn{2}{c}{$\begin{array}{c}\text { Koefisien } \\
\text { Tidak Terstandar }\end{array}$} & $\begin{array}{c}\text { Koefisien } \\
\text { Terstandar }\end{array}$ & Kesalahan \\
& Baku & Beta & & \\
\cline { 2 - 4 } & & B hitung & Signifikansi \\
\hline Konstan & $-11,802$ & 3,358 & & $-3,514$ & 0,001 \\
Konsentrasi Belajar & 0,101 & 0,035 & 0,438 & 2,905 & 0,007 \\
Lingkungan Belajar & 0,136 & 0,051 & 0,400 & 2,654 & 0,012 \\
\hline
\end{tabular}


Tabel 11. Hipotesis Ketiga

\begin{tabular}{lccccc}
\hline Model & $\begin{array}{c}\text { Jumlah } \\
\text { Kuadrat }\end{array}$ & Db & $\begin{array}{c}\text { Rerata } \\
\text { Kuadrat }\end{array}$ & F & Signifikansi \\
\hline Regresi & 216,372 & 2 & 108,186 & 23,545 & 0,000 \\
Residu & 151,628 & 33 & 4,595 & & \\
Total & 368,000 & 35 & & & \\
\hline
\end{tabular}

Dalam menguji model regresi berganda secara bersamaan terhadap dua variabel bebas maka dilakukan uji hipotesis dengan uji F. Dari model tersebut dilakukan uji hipotesis dengan statistik yang digunakan uji $\mathrm{F}$ didapatkan nilai signifikansi $=0,00$ yang nilainya tidak lebih besar dari $5 \%$.

Koefisien korelasi bersama antara konsentrasi belajar beserta lingkungan belajar terhadap hasil belajar matematika pada pembelajaran daring sebesar 0,588. Hal ini seperti terlihat pada Tabel 12. Adapun, koefisien parsial konsentrasi belajar terhadap hasil belajar maupun lingkungan belajar terhadap hasil belajar masing-masing terlihat pada Tabel 13. Dari analisis ini memberikan kesimpulan yang signifikan bahwa adanya pengaruh yang positif konsentrasi belajar siswa dan lingkungan belajar secara bersama-sama maupun secara parsial atas hasil belajar matematika.

Tabel 12. Koefisien Korelasi Bersama

\begin{tabular}{crrc}
\hline $\mathrm{R}$ & R Kuadrat & $\begin{array}{c}\text { Adjusted R } \\
\text { Square }\end{array}$ & Kesalahan Baku \\
\hline 0,767 & 0,588 & 0,563 & 2,14355 \\
\hline
\end{tabular}

Tabel 13. Koefisien Korelasi Parsial

\begin{tabular}{llc}
\hline & & Hasil Belajar \\
\hline Konsentrasi Belajar & Korelasi Pearson & 0,707 \\
& Signifikansi & 0,000 \\
\hline Lingkungan Belajar & Korelasi Pearson & 0,695 \\
& Signifikansi & 0,000 \\
\hline
\end{tabular}

Seberapa besar pengaruh konsentrasi maupun kondisi lingkungan belajar atas hasil belajar matematika pada pembelajaran daring dapat dilihat dari kontribusi efektif serta kontribusi relatif. Sumbangan efektif diperoleh dengan mengalikan koefisien terstandarisasi dengan koefisien korelasi Pearson, sedangkan penjumlahan kedua sumbangan efektifnya sama dengan koefisien determinasi linear ganda atau R kuadrat, dan rasio masing sumbangan efektif terhadap koefisien determinasi linear ganda menunjukkan kontribusi relatif (Budiyono, 2013). Menurut analisis, besarnya kontribusi efektif serta kontribusi relatif terhadap hasil belajar diuraikan pada Tabel 14. 
Tabel 14. Kontribusi Efektif dan Kontribusi Relatif

\begin{tabular}{lll}
\multicolumn{1}{c}{ Data } & \multicolumn{2}{c}{ Kontribusi } \\
& Efektif & Relatif \\
\hline Konsentrasi Belajar & $30,97 \%$ & $52,67 \%$ \\
Lingkungan Belajar & $27,83 \%$ & $47,33 \%$ \\
Jumlah & $58,80 \%$ & \\
\hline
\end{tabular}

Menurut hasil analisis ini, kontribusi konsentrasi belajar siswa dalam memberikan efek positif atas hasil belajar matematika pada pembelajaran daring sebesar 30,97\%, sedangkan kontribusi keadaan lingkungan belajar siswa memberikan efek positif atas hasil belajar matematika pada pembelajaran daring sebesar $27,83 \%$. Sementara itu, kontribusi konsentrasi belajar serta lingkungan belajar secara bersama-sama dalam memberikan efek positif atas hasil belajar matematika sebesar 58,80\%. Kontribusi kedua faktor ini sangatlah besar dalam memberikan efek positif atas hasil belajar matematika.

Menurut analisis di atas, adanya pengaruh positif konsentrasi belajar atas hasil belajar matematika menggambarkan bahwa semakin tinggi siswa berkonsentrasi dalam mengikuti pembelajaran daring, maka hasil belajar matematika juga semakin baik. Konsentrasi belajar itu dapat ditumbuhkan oleh diri siswa maupun diciptakan oleh guru melalui kegiatan pembelajaran yang didesainnya. Seperti yang diungkapkan bahwa siswa yang berkonsentrasi belajar berindikasikan siswa memiliki perhatian ketika pembelajaran, minat terhadap pembelajaran, respon secara verbal, maupun psikomotorik, serta pemahaman terhadap yang disampaikan oleh guru (Makmun, 2005; Manurung \& Simatupang, 2019). Pada pembelajaran daring, guru tidak mungkin mengawasi secara keseluruhan aktivitas siswanya. Untuk itu, guru dapat mendesain pembelajaran dengan memberikan stimulus yang dapat memancing respon siswa secara lisan maupun psikomotorik. Bagaimanakah caranya? Melalui model pembelajaran dan strategi pembelajaran yang inovatif dapat meningkatkan aktivitas belajar siswa (Yuliana \& Firmansah, 2018; Yuliana, Tasari, \& Wijayanti, 2017). Tak hanya itu, guru dapat mendesain pembelajaran dengan memberikan pertanyaan-pertanyaan secara lisan ketika pembelajaran daring, banyak tugas yang dikerjakan setelah pembelajaran daring, dan memberikan tugas untuk dipresentasikan dalam pertemuan tatap maya (Basar, 2021; Hanik, Nida, Nida, Lutfiatin, \& Widyaningrum, 2021). Pernyataan ini diperkuat dengan intensitas pemberian tugas ternyata menjadi salah satu segmentasi dalam pembelajaran (Yuliana, Aribowo, \& Setianingtyas, 2021). Karena pembelajaran daring lebih banyak pertemuan secara tatap maya, maka siswa membutuhkan lebih banyak perhatian dari gurunya (Mahmudi, Sulianto, \& Listyarini, 2020). Tak hanya pada saat pembelajaran daring, perhatian juga dapat diberikan sebelum pembelajaran daring dan setelah 
pembelajaran daring. Apabila indikasi konsentrasi belajar siswa sangat baik dalam mengikuti pembelajaran daring, wajar apabila siswa akan meraih prestasi belajar matematika yang baik pula. Akan tetapi, apabila siswa tidak berkonsentrasi dengan baik dalam mengikuti pembelajaran daring maka wajar pula hasil belajar yang diraihnya kurang memuaskan.

Dalam pembelajaran daring, kondisi lingkungan belajar siswa menjadi aspek yang perlu diperhatikan. Dari penelitian ini, kondisi lingkungan belajar siswa berefek positif atas hasil belajar matematika pada pembelajaran daring. Melalui pendampingan maupun tanpa pendampingan orang tua, lingkungan belajar siswa yang kondusif sangat diperlukan dalam pembelajaran daring. Kondisi lingkungan belajar siswa ditandai oleh beberapa indikasi yang meliputi perhatian orang tua, suasana di rumah, interaksi guru maupun antarsiswa, cara pembelajaran, lingkungan masyarakat, dan suasana media (Hasbullah, 2015; Slameto, 2015; Syah, 2002). Perhatian orang tua tentu dan suasana yang kondusif di lingkungan rumah menjadi sangat dibutuhkan bagi anak, misalnya perhatian akan kebutuhan perlengkapan sekolah, menyediakan tempat belajar yang memadai, bahkan sekedar hanya menanyakan sudah belajar atau belum. Pada pembelajaran daring ini, sebagian besar orang tua sudah memberikan fasilitas hp, smartphone, ataupun tablet yang sekaligus dilengkapi koneksi jaringan internet. Sangat umum, apabila siswa dengan smartphonenya sudah dapat memperoleh informasi dari media sosial secara cepat, misalnya tugas belajar dari guru, materi belajar, ataupun pengumpulan tugas. Bahkan era sekarang ini, interaksi belajar siswa lebih banyak dihabiskan melalui smartphone (Pandia, 2014). Kondisi ini memperkuat penelitian ini bahwa lingkungan belajar memiliki peran penting dalam pembelajaran daring (Kartini, Mimbar, \& Izrawati, 2021; Setyorini \& Wulandari, 2021). Sangat wajar, apabila lingkungan belajar siswa mempunyai pengaruh positif atas hasil belajar matematika siswa pada pembelajaran daring. Pernyataan itu sejalan dengan semakin kondusif lingkungan belajar siswa dalam mendukung pembelajaran daring, maka semakin bagus pula hasil belajar matematika.

Secara terpisah, konsentrasi belajar siswa dan lingkungan belajar siswa mempunyai efek positif atas hasil belajar matematika siswa pada pembelajaran daring. Siswa yang berkonsentrasi untuk mengikuti pembelajaran daring didukung dengan lingkungan belajar yang kondusif untuk belajar tentu akan semakin menambah semangat belajar siswa. Wajar, apabila siswa dengan konsentrasi belajar tinggi didukung dengan lingkungan belajar yang kondusif untuk pembelajaran daring, maka siswa akan mendapatkan hasil belajar lebih baik daripada tanpa didukung lingkungan belajar yang kondusif (Dores, Lisa, \& Vorina, 
2019; Yuzarion, 2017) ataupun siswa didukung oleh lingkungan belajar yang kondusif, tetapi tidak berkonsentrasi dalam mengikuti pembelajaran daring.

\section{KESIMPULAN}

Pada pembelajaran daring, pendampingan kedua orang tua sangat berperan dalam peningkatan hasil belajar siswa. Akan tetapi, tidak setiap orang tua mampu untuk memberikan pendampingan secara terus menerus karena berbagai alasan. Agar hasil belajar matematika siswa tetap maksimal, siswa perlu mempersiapkan diri untuk meningkatkan konsentrasi belajarnya ataupun kedua orang tua perlu menyediakan lingkungan belajar yang kondusif. Sesuai simpulan dalam penelitian ini bahwa konsentrasi belajar serta kondisi lingkungan belajar siswa secara terpisah maupun bersama-sama mempunyai efek positif atas hasil belajar matematika siswa pada pembelajaran daring. Penelitian ini dapat dikembangkan dengan mengambil ukuran sampel yang lebih besar. Tak hanya itu, penelitian ini dapat pula dikembangkan dengan menganalisis faktor-faktor yang mempengaruhi pembelajaran daring.

\section{REFERENSI}

Ahmadi, A. (2017). Psikologi umum. Jakarta: Jakarta: Rineka Cipta.

Anugrahana, A. (2020). hambatan, solusi dan harapan: pembelajaran daring selama masa pandemi covid-19 oleh guru sekolah dasar. Scholaria: Jurnal Pendidikan Dan Kebudayaan, 10(3), 282-289. https://doi.org/10.24246/j.js.2020.v10.i3.p282-289

Basar, A. M. (2021). Problematika pembelajaran jarak jauh pada masa pandemi covid-19. Edunesia: Jurnal Ilmiah Pendidikan, 2(1), 208-218. https://doi.org/10.51276/edu.v2i1.112

Budiyono. (2013). Statistika untuk penelitian. Surakarta: Surakarta: UNS Pers.

Dakhi, A. S. (2020). Peningkatan hasil belajar siswa. Jurnal Education and Devolepment, 8(2), 468-470. https://doi.org/10.36418/japendi.v1i3.33

Dores, O. J., Lisa, Y., \& Vorina, O. (2019). Analisis konsentrasi belajar siswa pada mata pelajaran matematika di kelas V SDN 20 SKPH Manis Raya. J-PiMat: Jurnal Pendidikan Matematika, 1(2), 57-68. https://doi.org/10.31932/j-pimat.v1i2.506

Febrianto, L. S., Dwidayati, N. K., \& Hendikawati, P. (2018). Perbandingan metode robust least median of square (LMS) dan penduga s untuk menangani outlier pada regresi linier berganda. Unnes Journal of Mathematics, 7(1), 83-95. https://doi.org/10.15294/ujm.v7i1.27381

Ghozali, I. (2016). Aplikasi analisis multivariate dengan program IBM SPSS 23 (Cetakan 8). Semarang: Badan Penerbit Universitas Diponegoro.

Gosal, L. C., Tarore, R. C., \& Karongkong, H. H. (2018). Analisis spasial tingkat kerentanan bencana gunung api lokon di kota tomohon. Jurnal Spasial, 5(2), 229237.

Hakim, L. (2020). Pendampingan orang tua dalam pembelajaran daring. Jurnal Ilmu Pendidikan Islam, 18(2), 192-220.

Halim, S. N. H., \& Rahma. (2020). Pengaruh lingkungan belajar, motivasi belajar dan 
kemandirian belajar terhadap hasil belajar matematika siswa Kelas XI IPA SMA N 9 Pangkep. MANDALIKA Mathematics and Educations Journal, 2(2), 102-109.

Hanik, E. U., Nida, M. K., Nida, H., Lutfiatin, N. N. R., \& Widyaningrum, T. (2021). Desain pembelajaran high risk dan low risk di sekolah indonesia kuala lumpur (SIKL) malaysia di era new normal. JKPD: Jurnal Kajian Pendidikan Dasar, 6(1), 24-36.

Hasbullah. (2015). Dasar-dasar ilmu pendidikan. Jakarta: PT. Raja Grafindo Persada.

Hays, W. L. (1976). Quantification in psychology. New Delhi: Prentice Hall.

Kartini, E., Mimbar, L., \& Izrawati. (2021). Persepsi mahasiswa dan pengaruh pola belajar, interaksi, dan lingkungan belajar terhadap pembelajaran daring masa pandemi covid19. Journal Ilmiah Rinjani (JIR), 9(1), 1-15.

Kusumaningrum, B., Singgih Kuncoro, K., \& Astuti Arigiyati, T. (2020). Pendampingan orangtua dalam pembelajaran daring di sekolah dasar: evaluasi pembelajaran daring selama masa pandemi covid-19. Inventa: Jurnal Pendidikan Guru Sekolah Dasar, 04(2), 145.

Mahmudi, A., Sulianto, J., \& Listyarini, I. (2020). Hubungan perhatian orang tua terhadap hasil belajar kognitif siswa. Jurnal Pedagogi Dan Pembelajaran, 3(1), 122-129. https://doi.org/10.23887/jp2.v3i1.24435

Makmun, A. S. (2005). Psikologi kependidikan perangkat sistem pengajaran modul. Bandung: Remadja Rosdakarya.

Manurung, M. P., \& Simatupang, D. (2019). Meningkatkan konsentrasi anak usia 5-6 tahun melalui penggunaan metode bercerita di TK ST Theresia Binjai. Jurnal Usia Dini, 5(1), 65.

Pahriji, I. A. (2021). Pengaruh lingkungan belajar terhadap motivasi belajar mahasiswa dalam pembelajaran jarak jauh selama pandemi. Jurnal Citra Pendidikan, 1(3), 380387.

Pandia, I. (2014). Penggunaan smartphone dalam mendukung prestasi belajar siswa SMPN 1 Kubung Kabupaten Solok Sumatera Barat. Jurnal Penelitian Komunikasi Dan Pembangunan, 15(2), 122-135.

Pangondian, R. A., Santosa, P. I., \& Nugroho, E. (2019). Faktor - faktor yang mempengaruhi kesuksesan pembelajaran daring. Seminar Nasional Teknologi Komputer \& Sains (SAINTEKS), 56-60.

Pujilestari, S., Dwidayati, N., \& Sugiman. (2017). Pemilihan model regresi linier berganda terbaik pada kasus multikolinieritas berdasarkan metode principal component analysis (PCA) dan metode stepwise. UNNES Journal of Mathematics, 6(1), 70-81. https://doi.org/10.15294/ujm.v6i1.11719

Putria, H., Maula, L. H., \& Uswatun, D. A. (2020). Analisis proses pembelajaran dalam jaringan (daring) masa pandemi covid-19 pada guru sekolah dasar. JURNAL BASICEDU: Research \& Learning in Elementary Education, 4(4), 861-872. https://doi.org/10.31004/basicedu.v4i4.460

Ratiwi, R. D., \& Sumarni, W. (2020). Peran orang tua dalam pendampingan belajar daring. Seminar Nasional Pasca Sarjana 2020.

Riinawati. (2021). Hubungan konsentrasi belajar siswa terhadap prestasi belajar peserta didik pada masa pandemi covid-19 di Sekolah Dasar Riinawati. Edukatif : Jurnal Ilmu Pendidikan, 3(4), 2305-2312.

Rizkiani, A., \& Septian, A. (2019). Kemampuan metakognitif siswa SMP dalam pembelajaran matematika dengan menggunakan pendekatan realistic mathematics education ( RME ). UNION: Jurnal Pendidikan Matematika, 7(2), 275-284.

Septian, A., Ramadhanty, C. L., Darhim, D., \& Prabawanto, S. (2021). Mathematical problem solving ability and student interest in learning using google classroom. Prosiding International Conference on Education of Suryakancana, 1(1), 155-161. 
Setyorini, I. D., \& Wulandari, S. S. (2021). Pengaruh media pembelajaran, fasilitas dan lingkungan belajar terhadap hasil belajar selama pandemi covid-19. Jurnal Profit: Kajian Pendidikan Ekonomi Dan Ilmu Ekonomi, 8(1), 19-29.

Slameto. (2015). Belajar dan faktor-faktor yang mempengaruhinya. Jakarta: Jakarta: PT. Rineka Cipta.

Suharsimi, A. (2013). Prosedur penelitian: suatu pendekatan praktik (edisi revisi). In Jakarta: Rineka Cipta. https://doi.org/10.1017/CBO9781107415324.004

Suryawan, I. P. P., \& Permana, D. (2020). Media pembelajaran online berbasis Geogebra sebagai upaya meningkatkan pemahaman konsep matematika. Prisma, 9(1), 108. https://doi.org/10.35194/jp.v9i1.929

Syah, M. (2002). Psikologi pendidikan dengan pendekatan baru. Jakarta: Remaja Rosda Karya.

Wahyuningsih, S., \& Djazari, M. (2013). Pengaruh lingkungan sekolah dan kebiasaan belajar terhadap prestasi belajar akuntansi siswa kelas XI IPS SMA Negeri 1 Srandakan. Kajian Pendidikan \& Akuntansi Indonesia, 2(1), 137-160.

Widayatun, \& Fatoni, Z. (2013). Permasalahan kesehatan dalam kondisi bencana:peran petugas kesehatan dan partisipasi masyarakat (health problems in a disaster situation: the role of health personnels and community participation). Jurnal Kependudukan Indonesia, 8(1), 37-52.

Yuliana, Aribowo, E. K., \& Setianingtyas, A. F. (2021). Persepsi mahasiswa terhadap profil dosen menggunakan analisis konjoin. Indonesian Journal of Educational Science (IJES), 03(02), 84-97.

Yuliana, \& Firmansah, F. (2018). The effectiveness of problem-based learning with social media assistance to improve students ' understanding toward statistics. Infinity Journal of Mathematics Education, 7(2), 97-108. https://doi.org/10.22460/infinity.v7i2.p97-108

Yuliana, Tasari, \& Wijayanti, S. (2017). The effectiveness of guided discovery learning to teach integral calculus for the mathematics students of mathematics. Infinity Journal of Mathematics Education, 6(1), 1-10. https://doi.org/10.22460/infinity.v6i1.222

Yuzarion, Y. (2017). Faktor yang mempengaruhi prestasi belajar peserta didik. Ilmu Pendidikan: Jurnal Kajian Teori Dan Praktik Kependidikan, 2(1), 107-117. https://doi.org/10.17977/um027v2i12017p107 